\title{
Marta Sala
}

Kielce

\section{WSPÓŁPRACA GALICYJSKICH I AUSTRIACKICH EMANCYPANTEK NA POCZ. XX WIEKU W ŚWIETLE PRASY LWOWSKIEJ I WIEDEŃSKIEJ}

Kwestia kobieca stała się jednym z ważniejszych problemów społecznych XIX stulecia. W tym okresie dość powszechnie panowało jeszcze przekonanie, że kobiety są istotami ułomnymi, szczególnie intelektualnie, niezdolnymi by wpływać na kształt rzeczywistości, nienadającymi się do dźwigania ciężaru spraw publicznych. Wielu uważało wówczas, że miejscem kobiety jest dom, kuchnia, pokój dziecięcy, salon, a jej jedynymi zadaniami powinno być rodzenie i wychowywanie dzieci, troska o gospodarstwo oraz dbałość o męża. Skutkiem tego była niemal zupełna nieobecność kobiet w polityce. Odmawiano im również wstępu do bibliotek i wyższych uczelni, zastanawiając się czy kobieta w ogóle powinna czytać książki. Sugerowano, że panie nie powinny nadużywać tej rozrywki, ponieważ z powodu słabości umysłu, mogły źle zrozumieć czytany tekst ${ }^{1}$. Przytaczano rzekomo naukowe dowody świadczące o tym, że „pojemność szarych komórek niewieścich jest znacznie mniejsza niż męskich, że nauka szkodzi urodzie i zdrowiu kobiety, utrudnia zamążpójście, prowadzi do szybszej śmierci"².

Miejsce kobiety w społeczeństwie wynikało z wielowiekowej tradycji, wpływów religii i obowiązującego prawa. Już pod koniec XVIII wieku pierwsze panie zaczęły dociekać przyczyn tak niskiej społeczno-politycznej sytuacji kobiet i szukać sposobów na zmianę swego statusu ${ }^{3}$. Jednak

1 Takiego zdania była Klementyna Hoffmanowa. Zob. K. Hoffmanowa, Dzieła Klementyny z Tańskich Hoffmanowej. O powinnościach kobiet, t. 9, Warszawa 1876, s. 198; A. Lisak, Miłość, kobieta i matżeństwo w XIX wieku, Warszawa 2009, s. 302.

2 A. Chwalba, Historia powszechna. Wiek XIX, Warszawa 2008, s. 614.

3 W 1791 r. Olympe de Gouges, córka rzeźnika wydała broszurę pt. „,Deklaracja praw kobiet i obywatelek" lecz zawarte w niej pomysły na poprawę sytuacji kobiet były zbyt 
to dopiero kolejne stulecie, a dokładniej jego druga połowa, przyniosło znaczne zmiany $\mathrm{w}$ tej kwestii. Chociaż prym w walce o równouprawnienie wiodły Amerykanki i Europejki, to ruch emancypacji kobiet objął w tym czasie wszystkie kontynenty. Na przestrzeni XIX stulecia udało się kobietom, zrzeszonym w licznych związkach, stowarzyszeniach i klubach kobiecych, wywalczyć ustawy sankcjonujące ich prawo własności, prawo do sporządzenia testamentu bez zgody męża (USA) ${ }^{4}$, a także złagodzenie niektórych konwenansów, co dało im możliwość podróżowania, czy spacerowania po mieście bez męskiej opieki. Panie uparcie lansowały nowy wzór aktywnej życiowo kobiety, uprawiającej sporty, samodzielnej, działającej w instytucjach obywatelskich. Z ogromną determinacją walczyły także o podniesienie poziomu wykształcenia kobiet. Lista wyższych uczelni, które dopuściły kobiety do swoich studiów, powoli wzrastała, zarówno w Europie, jak i w Ameryce. Rosła też społeczna akceptacja dla edukacji kobiet. Procesy te szybciej przebiegały we Francji, w Szwajcarii, krajach skandynawskich i Ameryce wolniej zaś w Niemczech, Austro-Węgrzech i Rosji. Liczba studentek na uniwersytetach powoli się zwiększała. I chociaż przed 1914 r. w większości krajów europejskich nie przekraczała $10 \%$ ogółu ${ }^{5}$, a studiujące kobiety napotykały na liczne trudności - np. we Francji, w której już w 1863 r. uzyskały prawo uczęszczania na wyższe uczelnie, nie miały prawa wstępu do Biblioteki Narodowej - to osiągnięcia pań w dziedzinie dostępu do pełnego wykształcenia, były ich ogromnym sukcesem.

Pod koniec XIX wieku, kiedy w wielu krajach wprowadzono powszechne lub bliskie powszechnemu prawo wyborcze, kobiety zaczęły żądać równych praw wyborczych z mężczyznami. Szczególnie aktywne w tej walce były brytyjskie sufrażystki (ang. suffrage - „prawo głosu”), które po odrzuceniu przez Parlament licznych petycji i wniosków, nie cofały się przed organizacją ulicznych manifestacji, kończących się walkami z policja, czy dramatycznymi gestami, jak przykuwanie się do żelaznego ogrodzenia przed siedzibą premiera lub rzucanie się pod kopyta królewskiego konia. Prowadziły strajki głodowe, a nawet wrzucały materiały wybuchowe do skrzynek pocztowych ${ }^{6}$. Silny ruch bojowniczek o prawa

radykalne. Ich autorkę zgilotynowano. Zob. A. Chwalba, Historia powszechna. Wiek XIX, Warszawa 2008, s. 610-611.

${ }_{4}^{4}$ Ibidem, s. 611.

${ }^{5}$ Ibidem, s. 615.

${ }^{6}$ Szerzej o angielskich sufrażystkach np. w: G. Bidwell, Bunt długich spódnic (Emelina Pankhurst), Katowice 1972; E. Pankhurst, My Own Story, London 1914; E. A. Hecker, A Short History of Women's Rights From the Days of Augustus to the Present Time. With Special Reference to England and the United States, New York-London 1911. 
wyborcze rozwinął się również w Stanach Zjednoczonych, a także w krajach skandynawskich - Norwegii i Danii.

Swoją kartę w historii walki o uczynienie z kobiet pełnoprawnych obywatelek zapisały na początku XX w. również galicyjskie emancypantki. Zanim jednak środowisko to skoncentrowało się na celach politycznych, podjęło szereg działań o charakterze humanitarnym, moralnym, oświatowym i socjalnym, zakładając i wspierając szkoły ludowe, ochronki, zakłady wychowania, towarzystwa miłosierdzia czy domy pracy. Jego przedstawicielki uczestniczyły w spotkaniach sympatyczek ruchu kobiecego, organizowały Zjazdy Kobiet Polskich, starały się śledzić programy i osiągnięcia współbojowniczek $z$ innych krajów europejskich oraz dzielić się z nimi własnymi przemyśleniami i postulatami. Zakładały też pierwsze czasopisma dla kobiet: „Przodownica”, ,Zorza”, „Nowe Słowo”.

Polski ruch emancypacyjny w Galicji składał się z dwóch nurtów: inteligenckiego (o charakterze radykalno-narodowym $\mathrm{z}$ odłamami ludowym i narodowo-demokratycznym) oraz socjalistycznego. Przedstawicielki pierwszego z nich dążyły do zrównania w prawach osób różnej płci pod względem wykształcenia, zatrudnienia, praw politycznych i cywilnych oraz obyczajów. Socjalistki natomiast za swój główny cel uznały gruntowną przemianę ustroju społecznego ${ }^{7}$.

Szczególnie aktywną działalność na rzecz zdobycia praw wyborczych toczyły Polki w Galicji od 1908 r. czyli od chwili powstania Komitetu Równouprawnienia Kobiet we Lwowie ${ }^{8}$ aż do wybuchu I wojny światowej

${ }^{7}$ Nie sposób tu wymienić wszystkich prac omawiających zagadnienia związane z ruchem kobiecym w Galicji. Kwestie te poruszali m.in.: B. Czajecka, "Z domu w szeroki świat...": droga kobiet do niezależności w zaborze austriackim w latach 1890-1914, Kraków 1990; M. Dulębianka, Polityczne stanowisko kobiety, Warszawa 1908; K. Dormus, Kazimiera Bujwidowa 1867-1932. Życie i działalność społeczno - oświatowa, Kraków 2002; J. Patrażycka-Tomicka, Zwiazek Równouprawnienia Kobiet we Lwowie. Przyczynek do historii równouprawnienia kobiet w Polsce, Kraków 1931; A. Harbrat, Jadwiga Petrażycka-Tomicka. Życie i działalność, Rzeszów 2001; Z. Romanowiczówna, Klaudynki. Kartka z dziejów patriotycznej pracy kobiet w Galicji, $w$ drugiej połowie ubiegłego stulecia, Lwów 1913; M. Ciechomska, Od matriarchatu do feminizmu, Poznań 1996; W. Najdus, O prawa obywatelskie kobiet w zaborze austriackim w: Kobieta i świat polityki. Polska na tle porównawczym w XIX i początkach XX wieku, pod red. A. Żarnowskiej, A. Szwarca, Warszawa 1994; M. Stępień, Narcyza Żmichowska, Warszawa 1968.

8 Powstał w lutym 1908 r. W dniu 3 czerwca 1909 r. został zalegalizowany pod nazwą Związek Równouprawnienia Kobiet z siedzibą we Lwowie. Związek ten był jedną z najbardziej aktywnych organizacji ruchu kobiecego na ziemiach polskich. Działały w nim m.in.: Maria Dulębianka, Zofia Grynbergowa, Melania Bersonowa, Olga Dekańska, Janina Dobrowolska, Janina Ryglówna, Anna Augustynowiczowa, Józefa Czarnocka, Maria Gerżabkowa, I. Laskownicka, Anna Lewicka, Halina Pawlewska, Maria Reuttówna, dr Filip Schleicher, Jadwiga Szczepańska, Jadwiga Tomicka, Stefania Wechslerowa. Por.: Ze Zwiąku równouprawnienia kobiet, „Kurier Lwowski” 1909, nr 262 z 7 czerwca 1909, s. 3-4; J. Tomicka-Petrażycka, Związek Równouprawnienia Kobiet... s. 8. 
w 1914 roku. Na początek XX wieku przypada również wzmożona aktywność austriackiego ruchu kobiecego?

Celem poniższego opracowania jest próba uchwycenia relacji między emancypantkami galicyjskimi i ich austriackimi „koleżankami”, odszukania ich ewentualnych wspólnych inicjatyw i płaszczyzn współpracy na drodze do zdobycia praw wyborczych.

Pierwszej, wartej zauważenia próby podjęcia tej kwestii można doszukać się w wydarzeniach roku 1905, kiedy to pod koniec października socjaldemokraci zorganizowali we Lwowie, ale także i w Wiedniu demonstracje, domagając się powszechnego prawa wyborczego. Między 24 a 25 października w obu miastach odbywały się zgromadzenia, zebrania, mitingi i marsze ${ }^{10}$. Ich uczestniczkami były również kobiety ${ }^{11}$. Delegacja robotnicza na czele z posłem Daszyńskim, złożyła wówczas na ręce marszałka Sejmu Krajowego hr. Badeniego petycję, w której domagano się "gruntownej reformy prawa wyborczego na podstawie równego, bezpośredniego, powszechnego i tajnego głosowania"12. Inicjatywa ta zbiegła się w czasie z pracami nad projektami zmian w ordynacji wyborczej, podjętymi przez kluby polityczne ${ }^{13}$.

Na fali powyższych robotniczych wystąpień i związanych z nimi postulatów, w swojej sprawie zabrały głos również kobiety. Dnia 24 października 1905 roku złożyły one, kierowaną do członków Sejmu Krajowego petycję, w której domagały się przyznania im praw obywatelskich. Pisały w niej:

Kobieta w Austrii a więc i w Galicji pozbawiona jest dotychczas wszelkich praw obywatelskich i traktowana jest na równi z małoletnim i bezwłasnowolnym. Dowodem tego zakazu jest pozbawienie prawa biernego wyboru, ograniczenie praw biernego wyboru, cenzura. Dowodzą one, że nie kobiecie jako człowiekowi przysługiwało do-

9 Zob. np. w: E. Fischer, Frauenbewegung in Österreich in: Furien in Uni-Form?, Innsbruck 1987, s. 23-27; G. Hauch, Frauen bewegen Politik: Österreich 1848-1938, InnsbruckWien 2009; W. Beutin, Zur Geschichte der Frau und der Frauenbewegung, mit Schwerpunkt auf Deutschland und Österreich in: Die Frau greift in die Politik, Hrsg. H. Beutin, Frankfurt, Wien 2010; I. Halwax, Die gesellschaftliche Stellung der Frau und die Anfünge der Frauenbewegung in Österreich (1866-1918), Wien 1994.

10 „Kurier Lwowski” 1905, nr 296, z dnia 26 października 1905, s. 4; Galizien, „Neue Freie Presse" 1905, nr 14789, z dn. 24 października 1905, s. 5; Wahlrechtdemonstration in Wien, „Neue Freie Presse” 1905, nr 14790, z dn. 25 października 1905, s. 5; Manifestacja ludu robotniczego, „Kurier Lwowski” nr 294 z dn. 24 października, s. 1.

${ }_{11}$ Manifestacja ludu robotniczego, „Kurier Lwowski” nr 294 z dn. 24 października, s. 1.

12 Ibidem.

13 „Kurier Lwowski” 1905, nr 296, z dn. 26 październka 1905 r., s 4; Galizien, „Neue Freie Presse” 1905, nr 14789, z dn. 24 października 1905, s. 5; „Neue Freie Presse” 1905, nr 14790, z dn. 25 października 1905, s. 5; Projekt reformy wyborczej, „Kurier Lwowski” 1905, nr 295, z dn. 25 października 1905, s. 1. 
tychczasowe jej prawo wyborcze lecz tylko reprezentowanemu przez nią majątkowi. Kobiety tędy domagają się praw obywatelskich, które się im należą z prostego poczucia słuszności. Żądając praw obywatelskich na pierwszym planie domagają się kobiety udzielenia im powszechnego, równego i tajnego czynnego i biernego prawa wyborczego do ciała ustawodawczego. [...] Nie ma więc powodu do wykluczenia woli kobiet w ukonstytuowanym państwie. Kobiety na równi z mężczyznami spełniają obowiązki względem państwa, płacą podatki, za czyny swoje odpowiadają i spoczywa na ich rękach wychowywanie małoletnich pokoleń ${ }^{14}$.

Ta, powstała na gruncie socjaldemokratycznym inicjatywa nie spotkała się z większą uwagą prasy wiedeńskiej ${ }^{15}$. Nie udało się również odnaleźć dowodów, by zyskała zainteresowanie działaczek austriackich. Mimo to warto o niej wspomnieć, ponieważ zawarte w niej sformułowania mogą sugerować, że Polki dostrzegły potrzebę nawiązania ściślejszych kontaktów z przedstawicielkami stowarzyszeń kobiecych z innych części monarchii austro - węgierskiej. Zaznaczając, że kwestia uzyskania praw wyborczych dotyczy nie tylko ich samych, podnosiły pośrednio sprawę porozumienia z emancypantkami austriackimi, współpracy z nimi i podjęcia wspólnego wysiłku w celu realizacji zakładanych celów.

Tymczasem wydaje się, że liczne organizacje kobiece w państwie austro - węgierskim, a więc także w Galicji, skoncentrowały się na swojej statutowej pracy.

Polki w 1906 r. zorganizowały dwa wiece, na których podnosiły kwestię pełni praw politycznych dla kobiet $^{16}$, wygłaszały liczne referaty i odczyty poświęcone temu tematowi (ich autorką była m.in. lwowska malarka Maria Dulębianka ${ }^{17}$ ) i borykały się z coraz bardziej widocznymi podziałami między socjaldemokratkami (Zofia Moraczewska, Maria Gerżbakowa)

14 Petycja na ręce wysokiego sejmu z dnia 24 X 1905, Archiwum Państwowe w Krakowie, C. K. Dyrekcja Policji w Krakowie, sygn. 658, k. 13-15.

15 Gazety wiedeńskie informowały swoich czytelników jedynie o manifestacjach robotniczych i pracach podjętych w Sejmach Krajowych nad reformą wyborczą - por.: Galizien, „Neue Freie Presse” 1905, nr 14789, z dn. 24 października 1905, s. 5; „Neue Freie Presse" 1905, nr 14790, z dn. 25 października 1905, s. 5.

16 B. Czajecka, Z domu w szeroki świat..., s. 223.

17 Dulębianka Maria (1861-1919) - malarka, publicystka, działaczka społeczna, aktywna działaczka ruchu kobiecego. Uczęszczała do pensji pani Maliszewskiej w Krakowie oraz pobierała naukę malarstwa u Jana Matejki. Studiowała w Paryżu i Wiedniu. Tematem jej obrazów często były kobiety. Wystawiała swoje prace w Krakowie, Warszawie i Paryżu. W 1889 r. poznała Marię Konopnicka, z którą później przez lata się przyjaźniła. W 1908 r. kandydowała jako pierwsza kobieta do Sejmu Krajowego. Członkini i przewodnicząca Związku Równouprawnienia Kobiet we Lwowie i założycielka Komitetu Obywatelskiej Pracy Kobiet. Podczas I wojny światowej zaangażowała się w pomoc rannym. Zmarła w 1919 r. na tyfus. Zob. M. Jaworska, Dulębianka Maria (1861-1919), PSB, t. 5, Wrocław 1939-1946, s. 457. 
a emancypantkami (Marię Dulębiankę, Janinę Aleksandrowicz, M. Weiblichowa i Karolinę Waydównę). Szczególnie aktywną działalność prowadziły: we Lwowie - Mokłowska, dr Salomea Perlmutter oraz jej siostry Anna i Laura Perlmutterówny, Maria Kelles-Krauzowa, Antonina Szererowa, Adolfina Grorzycka, w Krakowie - Cecylia Gumplowiczowa i Maria Turzyma (Wiśniewska). Emancypantki urządzały konferencje kobiece, organizowały zgromadzenia. Robotnice współdziałały z mężczyznami nie tworząc raczej odrębnych sekcji, ale szeroko rozwijając ruch kobiecy w obrębie PPSD. Strukturami tymi kierowały: dr Salomea Perlmutter-Trawiecka, dr Zofia Daszyńska-Golińska i Dorota Kłuszyńska ${ }^{18}$.

Komitety, związki i towarzystwa kobiece zrzeszające Austriaczki także podejmowały w tym czasie liczne inicjatywy, mające na celu zdobycie możliwości wpływania na życie kulturalne państwa. Apelowały o zakładanie szkół dla dziewcząt i reorganizację już istniejących, walczyły o dostęp do studiów uniwersyteckich na wszystkich typach uczelni i zdobycie dla kobiet praw wyborczych. Zyskiwały sojuszników i sympatyków w środowiskach męskich, którzy zabierali głos w sprawie politycznego równouprawnienia kobiet. Uczestniczyły $\mathrm{w}$ spotkaniach $\mathrm{i}$ mitingach, przedstawiając swoje cele i podejmując dyskusje w ważnych dla kobiet kwestiach.

W 1906 r. emancypantki austriackie utworzyły Österreichisches Frauenstimmrechtskomietee (Austriacki Komitet Praw Wyborczych dla Kobiet), który rozpoczął pracę nad zmianą politycznego położenia kobiet w państwie Habsburgów i aspirował do reprezentowania interesów pań na tym właśnie polu. Do pracujących w jego strukturach aktywistek należały m.in. Ernestine von Fürth, Gisela Urban, Henriette Herzfelder, Stefanie Nauheimer, Emma Hönigsberg ${ }^{19}$.

W 1908 r. działaczki Komitetu Równouprawnienia Kobiet we Lwowie, $\mathrm{w}$ porozumieniu z utworzonym przez stronnictwo demokratyczne lwowskiej rady miasta, Komitetem Reformy Gospodarki Miejskiej, postanowiły wysunąć kobiecą kandydaturę do Sejmu Krajowego. Walkę o mandat rozpoczęła Maria Dulębianka ${ }^{20}$. W wyborach 2 marca 1908 r. otrzymała 511 głosów, które oczywiście unieważniono. Rezultat ten można różnie oceniać $^{11}$. Z jednej strony liczba oddanych na nią głosów była niewielka,

18 B. Czajecka, Z domu w szeroki świat..., s. 318-322.

19 Np. w: E. Malleier, Jüdische Frauen in der Wiener bürgerlichen Frauenbewegung 18901938, Wien 2001, s. 59-65.

${ }^{20}$ Pod uwagę brano m.in. Marię Konopnicką licząc na jej olbrzymią popularność oraz Marię Wiśniewską (Turzymę) i Marię Dulębiankę. Ostatecznie ze względu na zły stan zdrowia Konopnickiej zdecydowana się na Dulębiankę.

${ }^{21}$ B. Czajecka, Z domu w szeroki świat..., s. 225; Kandydatura kobieca Maria Dulębianka, „Kurier Lwowski” 1908, nr 106, z 3 marca, s. 3. 
z drugiej jednak, biorąc pod uwagę brak doświadczenia kobiet w kwestii prowadzenia kampanii wyborczej oraz problemy z jakimi musiały się one zmierzyć, to wynik ten może być chyba uznany za pewien sukces. Natomiast z perspektywy ruchu kobiecego, kandydatura ta była spektakularnym manifestem i prezentacją stanowiska galicyjskich bojowniczek o równouprawnienie na forum publicznym ${ }^{22}$.

Echa tej inicjatywy pojawiały się na łamach „Kuriera Lwowskiego". Kwerenda przeprowadzona wśród periodyków wiedeńskich okazała się natomiast negatywna. Opiniotwórcza gazeta "Neue Freie Presse” informując swych czytelników o przebiegu i wynikach wyborów w poszczególnych częściach monarchii, skoncentrowała się na przedstawieniu nazwisk zwycięzców i zrelacjonowaniu incydentów, jakie miały miejsce w lokalach wyborczych. O rezultacie osiągniętym przez Dulębiankę nie wspomniała. Na jej łamach nie ukazały się również komentarze pochodzące od przedstawicielek austriackich środowisk kobiecych. Do marcowego i kwietniowego numeru „Neues Frauenleben” - publikacji podejmującej kwestie kobiece, nie udało się autorce niestety dotrzeć. Możliwe jednak, że redaktorzy wiedeńskich czasopism oraz tamtejsze działaczki feministyczne nie byli szczególnie zainteresowani, być może lokalnymi w ich odczuciu, sprawami Galicji ${ }^{23}$.

W świetle przytoczonych powyżej przykładów wydaje się, że o faktycznej współpracy pomiędzy ruchem kobiecym w Galicji i Austrii mówić można dopiero od 1911 r. Wówczas to, dnia 19 marca w ramach obchodów Dnia Kobiet ${ }^{24}$ lwowska partia socjaldemokratyczna oraz austriaccy socjaldemokraci zorganizowali we Lwowie i wielu miastach austriackich wielkie demonstracje pod hasłem praw wyborczych dla kobiet ${ }^{25}$.

22 Por.: Maria Dulębianka przed wyborami, „,Kurier Lwowski” 1908, nr 191 z 23 kwietnia, s. 1-2. B. Czajecka, Z domu w szeroki świat..., s. 223-224; M. Dulębianka, Polityczne stanowisko kobiety, Warszawa 1908, s. 3; Maria Dulębianka, „Kurier Lwowski” 1908, nr 103 z 1 marca, s. 1-2.; Kandydatura kobieca Maria Dulębianka, Ibidem, nr 106 z 3 marca, s. 3. Maria Dulębianka przed wyborami, „Kurier Lwowski” 1908, nr 191, z 23 kwietnia, s. 1-2. Maria Dulębianka, „Kurier Lwowski” 1908, nr 103, z 3 marca, s. 3.

${ }_{23}$ Die Parteiverhältnisse im galizischen Landtag, "Neue Freie Presse” 1908, nr 15639, z dn. 5 marca 1908, s. 6; Die Landtagswahlen in Galizien, „Neue Freie Presse“ 1908, nr 15638, z dn. 4 marca 1908, s. 7-8; Die Wahl in Galizien. Die Wahl in Lemberg, "Neue Freie Presse“ 1908, nr 15639, z dn. 5 marca 1908, s. 6.

${ }^{24}$ We wrześniu 1910 r. ustanowiono w Kopenhadze Międzynarodowy Dzień Kobiet. Pierwowzorem dla niego było urządzone w 1905 r. przez panie z Galicji i Śląska Święto Kobiet, w trakcie którego aktywistki zastrajkowały żądając dla siebie równouprawnienia. Por.: D. Wawrzykowska-Wierciochowa, Od przadki do astronautki..., s. 268.; Kronika Kobiet, pod red. M. Żmigrodzka-Wolska, Warszawa 1993, s. 411.; Sprawozdanie ze zjazdu, „Nowe Słowo" 1905, nr 20, 21.

25 Dzień Kobiet, "Głos Kobiet” dodatek do „Kuriera Lwowskiego” 1911, nr 128, z 18 marca 1911, s. 6. 
Galicyjscy działacze zaprosili licznie przybyłych uczestników i uczestniczki na uroczysty wiec, podczas którego swoje odczyty, wpisujące się w hasło dnia, wygłosili: panie Reizerówna, Perlmutter, Starosolska, Oleśkówna oraz pan Hankiewicz. Główny referat przygotowała Gumplowicz-Landau. Po uważnym wysłuchaniu podnoszonych w prelekcjach kwestii, członkowie spotkania przemaszerowali ulicami Lwowa w uroczystym pochodzie. Na jego czele szły kobiety niosące tablice z wypisanymi na nich postulatami feministycznymi. Wśród uczestniczek przeważały robotnice, ale obecne były również emancypantki ze środowisk inteligenckich i mieszczańskich, podkreślając tym samym, jak ważną dla wszystkich kobiet jest sprawa uzyskania praw politycznych ${ }^{26}$.

Podobnie przebiegały obchody również w Wiedniu. W zorganizowanej tam manifestacji wzięło udział ok 4 tyś uczestniczek, które zakończyły swój marsz pod ratuszem. Wydarzeń tych nie przegapiła prasa, publikując okolicznościowe artykuły. W stolicy Austrii ukazała się wówczas jednodniówka poświęcona w całości demonstracji. Swoje artykuły zawarli w niej socjaldemokraci - Adler i Bebel, a także panie: Klara Zetkin i Oda Olberg. Autorzy starali się pokazać, że sprawa politycznego równouprawnienia kobiet jest także sprawą mężczyzn i ściśle wiąże się z równouprawnieniem całego proletariatu ${ }^{27}$.

Kolejną płaszczyzną współpracy dla galicyjskich i austriackich emancypantek stały się zorganizowane na terenie Austro-Węgier Kongresy Kobiet.

Pierwszy z nich - Zjazd Kobiet Krajów Austriackich ${ }^{28}$ - odbył się w dniach 17-18 marca 1912 r. w Wiedniu. Jego celem miało być rozpoczęcie wspólnej walki kobiet o prawa wyborcze do parlamentu austriackiego oraz powołanie organizacji, koordynującej prowadzenie dalszych działań, aż do uzyskania równouprawnienia.

W pracach Zjazdu wzięły udział delegatki z Austrii, Galicji, Moraw, południowej Słowiańszczyzny i Śląska. Zabrakło natomiast kobiet z Węgier i Czech oraz przedstawicielek wiedeńskich stowarzyszeń kobiecych, które w nazwie nie miały słowa równouprawnienie. Węgierek nie zaproszono uznając, że i tak odmówią one udziału, zasłaniając się uznawaną przez siebie odrębnością Węgier. Organizatorkom nie udało się również

26 Por.: Ibidem; Dzień Kobiet, „Kurier Lwowski” 1911, nr 129, z dn. 20 marca 1911, s. 2.

27 O prawa wyborcze kobiet, „Kurier Lwowski” 1911, nr 129, z dn. 20 marca 1911, s. 6.

28 Pierwszy austriacki zjazd w Wiedniu, mający na celu rozpowszechnienia ruchu emancypacyjnego, odbył się 5-7 VI 1892 roku. Aktywnie uczestniczyły w nim Zofia Daszyńska, Mina Kautzki, Maria Gechwaz z Wiednia i Fanny Urschler ze Znojmu. O wiecu tym, ze względu na kontrowersyjne treści doniesiono do dyrekcji policji. Zob.: Pismo z C.K. Namiestnictwa do dyrekcji policji w Krakowie z dnia 22 V 1892, Archiwum Państwowe w Krakowie, Dyrekcja Policji w Krakowie, sygn. 1232, k. 1; Na zjazd kobiet w Wiedniu wyjechała. „Głos Kobiet”, dodatek do „Kurier Lwowski” 1912, nr 126, z dn. 17 marca 1912, s. 6. 
porozumieć z Czeszkami, które nie godziły się na prowadzenie obrad w języku niemieckim.

Reprezentację Polek na tym zjeździe tworzyły: Kazimiera Bujwidowa, Maria Dulębianka, Maria Gerżabkowa, Stanisława Malinowska i Janina Jabłońska. Wymienione uczestniczki podkreślając zaangażowanie środowisk galicyjskich $\mathrm{w}$ pracę na rzecz równouprawnienia politycznego kobiet, złożyły do parlamentu austriackiego petycję w tej sprawie, dla której zyskały ponadto poparcie posłów: dr Władysława Leopolda Jaworskiego, dr Juliusza Leo i dr Gerstemana.

Obradom zjazdu przewodniczyła przedstawicielka austriackiego Komitetu dla praw Wyborczych Kobiet Henriette Herzfelder ${ }^{29}$. Innymi emancypantkami austriackimi, które uczestniczyły w obradach były: Marianne Hainisch, Emma Hönigsberg, Maria Schwarz i Gisela Urban. Zjazd rozpoczął się od konferencji w Klubie Kobiet, na której poruszono kwestie, jakich praw wyborczych kobiety żądają od parlamentu austriackiego, sejmu czy gminy. W uchwalonej rezolucji delegatki domagały się czynnego i biernego prawa wyborczego dla wszystkich kobiet do wszystkich organów ustawodawczych, przy czym pozostawiono poszczególnym stowarzyszeniom swobodę, co do żądań kierowanych do Sejmów Krajowych czy gmin. Na kongresie zdecydowano się zachować bezpartyjny charakter ruchu kobiecego oraz stworzono wstępny plan powstania ogólnoaustriackiej organizacji, której celem stanie się walka o prawa kobiet. Szczegóły dotyczące funkcjonowania tej instytucji miały być omówione przez delegatki obecne na kongresie i poddane pod dyskusję na spotkaniach krajowych stowarzyszeń kobiecych. Sformułowane w trakcie tych dyskusji wnioski planowano przedstawić na kolejnym zjeździe, którego termin wyznaczono na $1913 \mathrm{r}^{30}$.

Zgodnie z poczynionymi założeniami, między 15 a 20 czerwca tego roku odbył się kolejny Kongres Kobiet. Tym razem panie zebrały się w Budapeszcie ${ }^{31}$. Wśród jego uczestniczek znalazły się Maria Dulębianka,

${ }^{29}$ Herzfelder Henriette (1865-1927) - austriacka pisarka i sufrażystka, członkini zarządu Federacji Austriackich Kobiet i współzałożycielka austriackich komitetów na rzecz praw politycznych kobiet, sekretarz Centralnego Urzędu ds. Ochrony Dzieci i Opieki Dziecka, redaktor "Zeitschrift für Frauenstimmrecht” - zob. Herzfelder Henriette w: Austriacki Stownik Biograficzny, 1959, t. II, s. 234.

30 O obradach Zjazdu Kobiet por.: M. Dulębianka, Zjazd Kobiet w Wiedniu „Głos Kobiet” dodatek do „Kuriera Lwowskiego” 1912, nr 148, z dn. 31 marca 1912, s. 5-6; L. Sinaiberger, Die erste österr. Stimmrechtskonferenz, "Neues Frauenleben” 1912, nr 4, s. 101-103; Die I. österreichische Frauenstimmrechts - Konferenz, "Zeitschrift für Frauenstimmrecht" 1912, nr 4, s. 1-3.

31 W dniach 11-12 kwietnia 1913 r. jako preludium planowanego Zjazdu Kobiet w Budapeszcie odbyła się w Wiedniu konferencja międzynarodowa zwolenników równo- 
dr Zofia Daszyńska-Golińska, Melania Bersonowa, Jadwiga Petrażycka-Tomicka, Maria Gerżabkowa i Maria Gawacka.

Zjazd, któremu przewodniczyła znana amerykańska sufrażystka Carrie Chapmann Catt, poświęcony był sposobom walki o prawa kobiet. Na tej płaszczyźnie doszło do sporów o formy i metody działań. Ostatecznie zdecydowano się jednak sięgać jedynie po środki konstytucyjne. Prowadzono również dyskusje na temat braku jedności między robotnicami a resztą kobiet $\mathrm{w}$ walce o równouprawnienie oraz poruszono kwestię handlu dziećmi. Podjęcie tej problematyki zaowocowało uchwaleniem rezolucji, w której uczestniczki kongresu wzywały rządy państw do zbadania przyczyn szerzenia się tego procederu.

W trakcie obrad swoje referaty zaprezentowały zebranym Jadwiga Tomicka, Maria Gerżabkowa oraz Maria Gawacka.

Na Kongresie nastąpiło oficjalne przyjęcie Związku Równouprawnienia Kobiet do Międzynarodowej Federacji oraz uroczyste wręczenie sztandaru. Organizacja, w której działały Polki otrzymała jednak jedynie status filii, gdyż Federacja stosowała zasadę, że członkiem może zostać tylko jeden komitet z każdego państwa. W przypadku wielonarodowej monarchii Habsburgów takie rozwiązanie było dość problematyczne. Oficjalną korespondentką galicyjskiego Związku została Jadwiga Tomicka, która regularnie zamieszczała sprawozdania z jego działalności w Jus suffragi. Bersonowa w imieniu polskich działaczek pisała natomiast do Common Cause w Londynie i Zeitschrift für Frauenstimmrecht.

$\mathrm{W}$ odczuciu samych uczestniczek ${ }^{32}$ Kongres ten miał głównie cel agitacyjny, mianowicie rozpowszechnienie idei równouprawnienia kobiet. Zdaniem Dulębianki, nie przyczynił się on do przekonania niezdecydowanych, ponieważ uczestniczyli w nim jedynie zwolennicy tej kwestii ${ }^{33}$.

uprawnienia kobiet. Uczestniczyło w niej około 800 przedstawicielek organizacji kobiecych m.in. Anna Furuijhelm ze Związku z Finlandii, Millicent Garett Fawcett przewodnicząca Narodowego Związku Stowarzyszeń dla Praw Wyborczych Kobiet w Londynie. Największym sukcesem tej konferencji było założenie Ligi Mężczyzn dla popierania politycznych praw kobiet. Por.: M. Dulębianka, VII Międzynarodowy kongres Federacji Związków równouprawnienia „Głos Kobiet” dodatek do „Kuriera Lwowskiego” 1913, nr 283, z 22 czerwca 1913, s. 5; Die Internationale Frauenstimmrechts - Konferenzin Wien, "Zeitschrift für Frauenstimmrecht" 1913, nr 6, s. 1-5.

32 M. Dulębianka, Kongres Kobiet w Budapeszcie „Kurier Lwowski” 1913, nr 340, z 25 lipca 1913, s. 2-3.

33 Ibidem; J. Petrażycka-Tomicka, Związek Równouprawnienia..., s. 27; Kongres kobiet w Budapeszcie, „Kurier Lwowski” 1913, nr 320, z 14 lipca 1913, s. 2-3. M. Dulębianka, Kongres kobiet w Budapeszcie, „Kurier Lwowski”, 1913, nr 326, z 17 lipca 1913, s. 2-3; Der VII. Internationale Frauenstimmrechts - Kongress in Budapest, "Zeitschrift für Frauenstimmrecht" 1913, nr 6, s. 5-9. 
Zamieszczone powyżej przykłady relacji istniejących pomiędzy galicyjskimi a austriackimi emancypantkami uwidaczniają ich skomplikowany charakter. $Z$ jednej strony pokazują pewien brak zainteresowania lub może bardziej brak większego entuzjazmu w uznaniu wzajemnych inicjatyw, z drugiej zaś pełną i owocną współpracę. I chociaż działaczkom nie udało się uniknąć ideowych antagonizmów, konfliktu poglądów i interesów, to ich próby szukania porozumienia są warte dostrzeżenia.

Wskazane wyżej trudności w walce o wspólną sprawę wynikać mogły z zaistniałej u progu XX wieku ogólnoeuropejskiej sytuacji politycznej i istnienia polskiej kwestii narodowej, od której całkowicie nie sposób było przecież uciec.

Współpracy nie ułatwiało zapewne także istnienie w obu omawianych regionach tak dużej liczby różnorodnych stowarzyszeń kobiecych, które mimo stawiania sobie podobnych celów niekoniecznie potrafily się ze sobą porozumieć. Przykłady solidarności, wsparcia i realizowanych wspólnie inicjatyw są więc niezwykle cenne.

Kobietom w monarchii Habsburgów, a więc także Polkom z Galicji, nie udało się przed wybuchem I wojny światowej zrealizować celu, o który tak walczyły - politycznego równouprawnienia. Ten wielki konflikt zbrojny zmienił jednak realia, w których przyszło im kontynuować swą aktywność. Omówienie tej kwestii wykracza jednak poza ramy niniejszego opracowania.

\title{
Zusammenfassung
}

\author{
DIE ZUSAMMENARBEIT DER GALIZISCHEN UND ÖSTERREICHISCHEN \\ EMANZIPIERTEN FRAUEN ANFANG DES 20. JAHRHUNDERTS \\ IM LICHT DER LEMBERGISCHEN UND WIENER PRESSE
}

Frauenfrage wurde eines der wichtigsten gesellschaftlichen Probleme des 19. Jahrhunderts geworden. Schon Ende des 18. Jahrhunderts begannen die ersten Frauen Ursachen der niedrigen gesellschaftspolitischen Situation der Frauen zu ermitteln suchen und sie suchten Mittel für Änderung ihrer Lage. Jedoch das nächste Jahrhundert, und genau die zweite Hälfte, brachte wesentliche Änderungen in dieser Frage. Obwohl im Kampf um die Gleichberechtigung Amerikanerinnen und Europäerinnen die erste Geige spielten, umfasste die Emanzipationsbewegung der Frauen alle Kontinente. Am Anfang des 20. Jahrhunderts im Zusammenhang mit der Kampagne für allgemeine Wahlrechte kam es zur starken Belebung der Frauenbewegung. Ihr Kapitel in der Geschichte des Frauenkampfes um Gleichberechtigung schrieben auch die emanzipierten Frauen aus Galizien. Die dargestellte Bearbeitung ist ein Versuch für die Forschung der Zusammenarbeit zwischen diesem Umfeld und Frauenbewegung in Österreich. Die Ebene für diese Kontakte bildeten Frauenkongresse, die gleich vor dem Ausbruch des Ersten Weltkriegs in Wien und Budapest organisiert wurden. Das Grundziel dieser Begegnungen war der gemeinsame 
Kampf um aktives und passives Wahlrecht für alle Frauen in alle Gesetzgebungsorgane in Staaten. Die Polinnen nahmen aktiv in Arbeiten dieser Begegnungen teil, hielten Vorträge und schrieben Berichte für die feministische Presse u. a. für "Jus suffragi“ und "Zeitschrift für Frauenstimmrecht“. Die Zusammenarbeit im Kampf um die Gleichberechtigung, die Anfang des 20. Jahrhunderts begonnen wurde, erschwerte der Erste Weltkrieg. 